Old Dominion University

ODU Digital Commons

\title{
Review: Environmental Design: Architecture, Politics, and Science in Postwar America
}

Robert Wojtowicz

Old Dominion University, rwojtowi@odu.edu

Follow this and additional works at: https://digitalcommons.odu.edu/art_pubs

Part of the Architectural History and Criticism Commons, Art Education Commons, and the Other Architecture Commons

\section{Original Publication Citation}

Wojtowicz, R. (2021). Review: Environmental design: Architecture, politics, and science in postwar America. Journal of the Society of Architectural Historians, 80(2), 230-231. https://doi.org/10.1525/ jsah.2021.80.2.230

This Book Review is brought to you for free and open access by the Art at ODU Digital Commons. It has been accepted for inclusion in Art Faculty Publications by an authorized administrator of ODU Digital Commons. For more information, please contact digitalcommons@odu.edu. 
cultural landscape of these spaces. His research and periodization offer students and instructors in cultural landscape studies, architecture and architectural history, and historic preservation a serious and useful framework for engaging with these buildings that has previously been largely absent from the literature.

Jacobs's research also highlights an unresolved tension in studies of suburban domestic design, where on the one hand we see increasing uniformity in popular suburban housing, while on the other we see indications of creative variation and regional difference. Jacobs acknowledges this tension, stating that for every trend he identifies, there will inevitably be numerous variations and exceptions (8). These differences and variations, however, find little treatment or attention here. The effect of the national viewpoint that Jacobs presents is much like that of the suburban aerial photo: from far enough away, everything begins to look the same. While this perspective is not without its merits, the literature on domestic suburban design has long suffered from an overemphasis on prescriptive norms and national scales, a focus that overshadows or ignores the messy, and often more interesting, realities of suburban spaces. Jacobs gives glimpses of this underlying creative messiness, such as when he describes how builders and consumers actively made and remade domestic space. Builders' marketing tactics, market research, and market testing of houses at the local and regional levels, as Jacobs reveals, raise questions about how national trends intersect with regional and local specificities, and which has greater influence. The rigorous energy and attention that builders and their professional associations paid to design matters during the postwar period, as well as builders' communication with their local markets, signal a design community deeply engaged at both scales.

Beyond our understanding of suburban homes as objects, the argument in Detached America that interaction between builders and consumers shaped the American suburban domestic landscape is important and deserves more attention. While Jacobs leaves largely unexamined the impact of the consumer-producer dialogue at local and regional levels, his research effectively demonstrates that when we get closer to ground level, there is still much to learn about the suburbs, their makers, and the people who call them home.

ELAINE BROWN STILES

Roger Williams University

\section{Avigail Sachs}

Environmental Design: Architecture, Politics, and Science in Postwar America

Charlottesville: University of Virginia Press, 2018, 231 pp., 45 b/w illus. \$39.50 (cloth), ISBN 9780813941271

How is a discipline born, or, alternatively, how is an existing discipline reimagined? These are the questions Avigail Sachs ponders and, to a large degree, answers in her thoughtful, meticulously researched study of postwar architectural education, Environmental Design: Architecture, Politics, and Science in Postwar America. The backdrop is the rise of the science-based research enterprise within American higher education as it was supported by such federal agencies as the National Science Foundation. Departments and schools of architecture, many of them still adjusting to the Bauhaus-inspired reforms that had only recently upended traditional, BeauxArts educational practices, sought renewed relevance within this context. As developed during the 1950s and 1960s, environmental design offered a new, more comprehensive way of thinking about architectural pedagogy and practice that continues to inform the discipline today.

Sachs's discussion ranges across familiar academic territory, much of it bounded by the Ivy League, including Harvard's Graduate School of Design, the University of Pennsylvania's Graduate School of Fine Arts, Yale's School of Art and Architecture, and Princeton's School of Architecture and Urban Planning, but it focuses particularly on the University of California, Berkeley's College of Environmental Design (CED), which was formed in 1959 when the departments of architecture, landscape architecture, and city and regional planning were all brought together under a common banner. Led by William Wurster, who first rose to prominence as a practitioner of Bay Region modernism, the CED became a national locus for intellectual inquiry regarding architectural "research" as a necessary counterpart to architectural practice.
Earlier, it should be noted, Wurster had served as dean of MIT's School of Architecture, overseeing its transformation into the more broadly focused and researchoriented School of Architecture and Urban Planning. Environmental design as a defined area of study eventually became codified in the monikers of research centers and professional societies, most notably the Environmental Design Research Association.

Exactly just what constituted environmental research and design-and how to get there from the standpoint of architectural education-was the subject of serious and protracted debate among both academics and professionals during these formative years. Methodologies employed in the social and behavioral sciences, especially psychology, offered one potential pathway, leading to the establishment of subspecialties such as environment-behavior studies and man-environment relations. Cybernetics and its close cousins, operations research and systems analysis, offered another, more rational approach, even as they inevitably collided with the less rational aspects of the creative process. Participatory design was yet a third route. Sachs traces its origins in part to "squatting," a technique developed by William W. Caudill of the Texas firm Caudill Rowlett Scott, in which designers immersed themselves fully in a community setting to gather feedback carefully from various stakeholders before proposing a design. User participation, moreover, would assume increasing urgency as social unrest began to rock American inner cities in the mid- to late 1960s. As a field, architecture had an identity problem that extended directly to its membership: the elitism of the Beaux-Arts aesthetes merely had been replaced by the elitism of the "scientific" professionals, and neither was particularly welcoming to women or underrepresented minorities.

There was an inevitable reaction to environmental design as a field even before it reached maturity. From the rear guard, some professionals complained that when students were burdened with the demands of nonstudio coursework, they became less proficient in drawing. From the vanguard, those academics under the influence of postmodern literary theory would, by the early 1980s, sideline environmental discourse as antithetical to what they perceived as architecture's eternal values. In this larger, 
discordant context, Sachs's analysis of Robert Venturi and Denise Scott Brown's Studio LLV, the architecture seminar that lay behind their seminal 1972 text (with Steven Izenour) Learning from Las Vegas, is particularly insightful. In attempting to combine the formal and the social, but lacking the time to do justice to the latter, students inevitably became mired in their own aesthetic biases - a situation that raised the question of what was truly "learned."

In researching Environmental Design, Sachs combed through more than a dozen archives, unearthing reports, program manuals, conference proceedings, and curricula, in addition to examining better-known published studies by Christopher Alexander, Rachel Carson, James Marston Fitch, Jane Jacobs, Kevin Lynch, and William Whyte, among others. Interspersed throughout her text are photographs as well as diagrams drawn from these sources, some remarkably prescient, others quaintly outmoded, and all fascinating. Key intellectual forebears pop up from time to time, including John Dewey, Patrick Geddes-whose role in this narrative could have been expanded significantly—and Lewis Mumford. In fact, Sachs identifies Mumford's "Housing" essay for the Museum of Modern Art's 1932 Modern Architecture: International Exbibition as the catalyst for the entire movement. Nevertheless, environmental design's truest and most sustained champion turns out to have been Catherine Bauer, Mumford's onetime collaborator who rose to prominence as a housing reformer and subsequently became Wurster's marital, academic, and intellectual partner. Bauer's relentless advocacy for a more inclusive, participatory approach informed the best ideas that emerged from the CED and the environmental design movement writ large. In a long-overdue acknowledgment of her outsize role, Wurster Hall on the Berkeley campus was renamed Bauer Wurster Hall in late 2020.

Ever since Giorgio Vasari elevated architecture from manual to intellectual status, self-scrutiny among its practitioners has been a constant. Sachs shines an important spotlight on how this introspective process accelerated in the postwar years. In the end, a new discipline was not born, and an existing discipline was only partially reimagined. "Ultimately, architecture as environmental design was a theory of the profession and its role in democratic social action, or a theory of practice, and not a theory of architecture," she writes in the book's conclusion. "As such it offered a vision of what architects should be, but it did not, and could not, provide overarching characterizations of architecture. Indeed, it was often the conflation of these realms - the attempt to explain the art of architecture through its practicethat led to divisive results" (164). Such ongoing divisions notwithstanding, that contemporary architects remain engaged in environmental discourse would seem essential, given the potentially dire outcomes facing the planet in the twenty-first century.

ROBERT WOJTOWICZ Old Dominion University

Helen Lefkowitz Horowitz

Traces of J. B. Jackson: The Man Who Taught Us to See Everyday America

Charlottesville: University of Virginia Press,

2020, 328 pp., 16 color and 35 b/w illus.

$\$ 39.50$ (cloth), ISBN 9780813943343

As a junior at the University of California, Berkeley, in the 1990s, I enrolled in Paul Groth's class Cultural Landscapes. On the first day, I listened to Groth talk about highways, barns, and commercial storefronts as the "ordinary built environment," a subject that I had not known existed, and that has guided my work ever since. At the time, I did not realize that my academic journey was directly influenced by J. B. Jackson; Groth was a longtime teaching assistant for Jackson's course History of the Man-Made Environment, and he had built his class on Jackson's slides, research, and findings.

It is hard to measure the full extent of J. B. Jackson's influence on the disciplines of architectural history, American studies, and geography. On the one hand, Jackson was the founder, main publisher, and editor of Landscape magazine from 1951 to 1968 , the writer of several collections of essays, a distinguished faculty member at Harvard and Berkeley for almost two decades, and the recipient of numerous accolades, including the 1995 PEN Award for the Art of the Essay. On the other hand, he did not follow the conventions of scholarly writing (his work did not include scholarly monographs) or academic employment (he did not work full-time as a professor at one institution, where he could have further shaped programs and areas of scholarship). In Traces of 7. B. Fackson, Helen Lefkowitz Horowitz quotes a 1973 letter in which Jackson's brother told him, "You have single-handedly created a field of study" that "will soon become an established discipline" (201). As a historian of the built environment (or cultural landscape scholar) myself, I have often felt that the study of ordinary landscape histories and social histories of built environments has been marginal to the fields of geography and architectural history. In recent years, however, architectural historians and theorists have begun to reinvigorate socially oriented research and the study of the everyday built environment; given these developments, revisiting Jackson's work now is not only instructive but also timely.

Horowitz's intimate and thorough biography reflects on Jackson's work as well as on his legacy. Starting out chronologically and emphasizing the more thematic aspects of Jackson's life, Horowitz reconstructs "traces" of his upbringing, early education, relationships, and wartime service, contextualizing both his interest in ordinary landscapes and his changing personal orientation toward issues of race, class, religion, and sexuality. She shows how Jackson's wartime service shaped both his interest in sketching and his close attention to maps, geography, and built landscapes. These interests in turn inspired Jackson's sensitive and insightful approach toward landscapes later in life. Horowitz also deftly explores her own evolving personal relationship with Jackson, leveraging their interactions to gain insight into Jackson's character and ideas. The heart of the book lies in its most engrossing chapters, which address his ideas and writings as well as his public speaking and teaching.

Filled with salient quotations from Jackson's published work and field journals, correspondence, and interviews, Horowitz's book shows how Jackson continually redefined the terms vernacular and landscape as the field of landscape studies took shape. For Jackson, landscape "encompassed the full imprint of human societies on the land" (1). Landscape could be viewed as an "expression of a culture, of a way of life," and "as a complex and moving work of art, the transcript of a significant collective experience" (99). In many ways, it is that collective experience that Jackson doggedly pursued 